INTERNATIONAL JOURNAL OF RESEARCHES IN BIOSCIENCES, AGRICULTURE AND TECHNOLOGY (C) VISHWASHANTI MULTIPURPOSE SOCIETY (Global Peace Multipurpose Society) R. No. MH-659/13(N)

www.vmsindia.org

\title{
EFFECT OF SEED GRADE ON QUALITY PARAMETERS OF LOBIA IN STORAGE
}

\author{
Prachi Lambat ${ }^{1}$, Vipin Babhulkar ${ }^{2}$, Sanjiv Charjan ${ }^{3}$, \\ Rajesh Gadewar ${ }^{4}$, Ashish Lambat ${ }^{5}$ and Ramesh parate ${ }^{6}$ \\ ${ }^{1}$ Shri Mathuradas Mohata Science College, Nagpur MS) \\ 2,3,6.Dr. PDKV's College of Agriculture Nagpur. \\ 4,5Sevadal Mahila Mahavidyalaya and Research Academy, Nagpur
}

\begin{abstract}
:
One of the major problems encountered in Lobia production is the lack of good quality seeds at the time of sowing. In the present investigation freshly harvested seeds of the Lobia, were graded into small, medium and bold seeds. The graded seeds stored in jute bags upto next sowing season (Oct. 2015) in the present investigation the observation on different tests were taken bimonthly from November -2015 to June - 2016. It was observed that the recovery percentage was significantly higher in medium size seeds as compared to small and bold size seeds. The 100 - seed weight was significantly maximum in bold size seeds. Among the seed grades, medium size seeds showed significantly higher seed viability and field emergence percentage as compared to small, bold and ungraded seeds. Seedling vigour parameters viz. speed of germination, length of seedling, seedling dry weight and seed vigour index was higher in bold seeds but it is at par with medium sized seeds. It was also noted that Aspergillus Sp., nFusarium Sp., CurvualariaSp., Rhizopus Sp., and Penicillium Sp. were the most commonly occurring fungi irrespective of Lobia seed sizes during storage. But total incidence percentages of fungi were observed higher on small size seeds as compared to other size seeds. The medium size seeds showed significantly higher seed viability, field emergence percentage and lesser invasion of fungal flora during storage up to coming Kharif Season sowing time

Keywords: Lobia, Recovery Percentage, Seed Viability, Field Emergence Percentage.
\end{abstract}

\section{Introduction:}

Lobia is a rich source of protein and oil but it is yet to gain impetus in our country. One of the major problems encountered in Lobia production is lack of good quality seeds. The poor quality seeds lead to poor and erratic field emergence and failure of seedling establishment in the field which subsequently results into low productivity of the Lobia. The desirable attributes of quality seed is uniformity in size. It is therefore, desirable to determine the optimum size of seed that promote better germination, growth vigour and yield. Evidences of seed size effects on various aspects of plant growth and storability of seeds was also reported in related crops by Tiwari and Gupta (1981), Dharmalingam and Basu (1991), Vyas et al. (1990), Charjan and Tarar. (1992), Tiwari and Gontia. (2001) and Charjan et al. (2006). Since information on this aspect is meagre in Cowpea. Hence, an experiment was conducted to study the maintenance of Lobia seed qualities from post harvest operations to next sowing season.

\section{Material and Methods:}

Lobia were used in various phases of this study, produced in 2015. The hand threshed seeds were cleaned, dried to safe moisture level for storage $(10 \pm 1 \%)$. Seed size grading was done using round perforated metal sieves having hole diameter $13 / 64$ inch $(5.2 \mathrm{~mm}), 12 / 64$ inch $(4.8$ $\mathrm{mm}$ ) and $11 / 64(4.4 \mathrm{~mm})$. The seeds retained by the above sieves were designed as G1, G2 and G3 respectively, while the bulk seeds (ungraded ) as UG. Processing recovery was calculated as Processing Recovery \% = W1/ W0 x 100 . Whereas, $\mathrm{W} 1$ = Wt. of material retained over the sieve. $\mathrm{WO}=\mathrm{Wt}$. of total material taken for grading on the sieve.
By drawing the required number of seed samples from G1, G2 G3 and UG to evaluate the performance of the seed lots in various laboratory studies, following test and observations were made (i) weight of 100 seeds from a total of $4 \times 100$ seeds on dry weight basis (ii) germination percentage on the basis of normal seedling under laboratory conditions in between towel paper media (Anon. 1985), (iii) length of plumule and radical on $8^{\text {th }}$ day of germination test on ten randomly selected normal seedlings (iv) speed of germination (Magurie, 1962), (iv) seedling dry weight on $8^{\text {th }}$ day of germination test on ten randomly selected normal seedling (vi) seedling vigour index (Abdul-Baki and Anderson, 1973) and (vii) field emergence percentage. For field emergence test, sowing of Lobia seeds was done in randomized block design with four replications with inter and intra-row spacing of 1 feet and 6 inches respectively. Observations for field emergence were recorded daily and finally the established seedlings were counted after one month of sowing. The experimental data was statistically scrutinized as per Panse and Sukhatme (1967).

The graded seeds of Lobia G1, G2, G3 and UG were packed in fresh cloth bags of size $20 \mathrm{~cm} \times 30 \mathrm{~cm}$. The cloth bags were store in wire-mesh almirah in masonary building having cement walls, roof and floor, under ambient temperature $\left(12\right.$ to $\left.46.7^{\circ} \mathrm{C}\right)$ and relative humidity (25.1 to $89.4 \%$ ) for 8 months (Nov. 2015 to June 2016) the observations on germination percentage, length of seedling, speed of germination, seedling vigour index, field emergence percentage and incidence percentage of Fungal Flora (Anon. 1976) were recorded bimonthly intervals. 


\section{Result and Discussion:}

It was observed from the Table 1 that the medium size seeds (G2) recorded the significant highest processing recovery $(96 \%)$ which is closely followed by small size seeds (89\%) and large size seeds (85\%) This fact was supported by kausal et al. (1993) Charjan et al. 2011. The 100-seed weight of each seed size showed a close association with the size of seeds. There was decreasing trend in 100-seed weight with the decrease in seed size. Aquire and Nakane (1983) reported that the seed weight is directly proportional to seed size. In the present study, the large size seeds recorded to maximum 100 seed weight $(11.4 \mathrm{~g})$ which is closely followed by medium size seeds (10.6 g), ungraded seeds (9.6 g) and small size seeds (8.7 g) the maximum 100-seed weight in large and medium size seeds indicating the possibility of well filling of these seeds in the pod with well developed cotyledons embryo with reserve food material. the small size seeds showed significantly minimum 100seed weight this might be due to the reason that presence of immature and shriveled seeds. This finding is in good accord with those reported by Tiwari and Gontia. (2001) and Charjan et al. (2006) and Charjan et al. (2011).

The germination percentage of each seed size different with respect to seed size and there was decreasing trends with the decrease in seed size. The maximum germination (95\%) was recorded in large size (G1) seeds which is closely followed by $(94 \%)$ in medium size seeds (G2), $88 \%$ in ungraded seeds (UG) and $80 \%$ in small size seeds (G3). Though maximum germination percentages were recorded percentage as compared to medium size seeds. The difference of germination between large (95\%) and medium $(94 \%)$ size seeds was very less but processing recovery was maximum in medium size seeds $(96 \%)$ as compared to large size seeds $(85 \%)$. Thus in Soyabean, medium size seeds is economical for obtaining maximum processing recovery and good germinability. Gurbanov and Berti (1970) reported that the increased germination percentage in bigger seeds is delivered to the due to increased activity of redox-enzyme in bigger seeds helping in breaking down the complex food material into simple soluble sugar. The probable reason for low germination in the small seeds may be the presence of immature and shriveled seeds. Similar observations have been reported by Kala Kannavar et al. (1989) Charjan and Tarar (1991), Charjan and Tarar (1992), Tiwari and Gontia (2001) and Charjan et al. (2006) and Charjan et al. (2011). Similarly, large and medium size seeds also found superior for seed germination test, seedling length, seedling dry weight, seedling vigour index test and field emergence test (Table. 1) McDaniel (1969) reported that the increase root length, seedling dry weight, and seedling dry weight, and seedling vigour index from bigger seeds may be due to efficient utilization of large food reserves and greater amount of production of energy which are positively correlated with seed size. Similar observations have been reported by Charjan and Tarar (1991), Charjan and Tarar (1992), Tiwari and Gontia (2001) and Charjan et al.(2006) and Charjan et al- (2011) on sunflower, safflower, paddy, cowpea soyabean respectively.

In the present study the Table 2 indicated that the germinability of Lobia seeds decreases with the increase in storage period irrespective of seed size. A sharp decline in germination percentage occurred in small size seeds during storage of 9 months (Nov. 2015 to June, 2016) as compared to ungraded seeds. Tiwari and Gupta (1981) also reported that the small seeds showed highest loss in germinability followed by mixed grade and large seeds after 8 months of storage. The results suggested that medium size seeds were to undergo the least amount of loss of germinability thereby retaining the initial germinability to a great extent after 8 months of storage under ambient condition as compared to ungraded and large size seeds, the seed coat mechanically damage more as compared to medium and small size seeds. The mechanically damage seeds showed higher rate of respiration during storage which are known to cause early reduction in germinability (Barriga, 1961). Vyas et al. (1991) reported that bold seed varieties showed poor performance in germinability and seed quality in subsequent storage. Seed quality parameters such as speed of germination, seedling length, seedling dry weight, seedling vigour index and field emergence test also showed the similar trends of germination test.

The incidence percentage of fungal flora recorded on different size seeds of Lobia storage after 8 months and initial is given in Table. 3 . With the advance of storage periods the percent incidence percentage of fungal flora increased irrespective of seed size. The Aspergillus sp., Curvulariasp., Fusarium sp., Rhizopus sp. and Penicillium sp. were most commonly occurring fungi irrespective of seed size and storage periods. Christensen (1973), Shrivastava and Gupta (1980), Charjan, Charjan et al. (2011) Gupta (1996) also reported that the increase in percentage of storage fungi and loss in field fungi during storage. Dwivedi and Shukla (1990) reported that the storage fungi were the most commonly occurring fungi irrespective of period and container of storage. The maximum number of fungal colonies did develop on small size seeds which are closely followed by ungraded, large and medium size seeds. This might be due to immature and shriveled seeds. Similar results also reported by Reddy and Subhayya (1980), Charjan and Tarar (1993) and Charjan et al. (2011). Large size seeds showed more number of pared to medium size seeds this might be due more mechanical damage to the seed coat which attract more fungal flora due to higher leaching of sugar. Similar observations have been reported by Barriga (1961). 


\section{Conclusion:}

The result suggest that medium size seeds of Lobia are superior in respect to processing recovery germinability, seedling vigour, field emergence and lower invasion of fungal flora as compared to other size seeds. This study also revealed that medium size seeds were good stores for germination and seedling vigour as compared to other size seeds upto the next planting season.

Table 1: Effect of different seed size on qualities of Lobia seeds.

\begin{tabular}{|l|c|c|c|c|c|c|c|c|}
\hline $\begin{array}{l}\text { Soyabean } \\
\text { seed grade }\end{array}$ & $\begin{array}{c}\text { Processing } \\
\text { recovery } \\
(\%)\end{array}$ & $\begin{array}{c}100- \\
\text { seed } \\
\text { weight } \\
(\mathrm{g})\end{array}$ & $\begin{array}{c}\text { Germination } \\
(\%)\end{array}$ & $\begin{array}{c}\text { Speed of } \\
\text { germination } \\
\text { (Length/Day) }\end{array}$ & $\begin{array}{c}\text { Seedling } \\
\text { length } \\
(\mathrm{cm})\end{array}$ & $\begin{array}{c}\text { Seedling } \\
\text { Vigour } \\
\text { Index } \\
\text { (SVI) }\end{array}$ & $\begin{array}{c}\text { Seedling } \\
\text { dry } \\
\text { weight } \\
(\mathrm{g})\end{array}$ & $\begin{array}{c}\text { Field } \\
\text { emergence } \\
(\%)\end{array}$ \\
\hline $\begin{array}{l}\text { G1 } \\
(5.2 \mathrm{~mm})\end{array}$ & 85 & 11.4 & 95 & 41.3 & 54.91 & 4405 & 1.59 & 81.2 \\
\hline $\begin{array}{l}\text { G2 } \\
(4.8 \mathrm{~mm})\end{array}$ & 96 & 10.6 & 94 & 41.1 & 52.94 & 42.91 & 1.53 & 80.8 \\
\hline $\begin{array}{l}\text { G3 } \\
(4.4 \mathrm{~mm})\end{array}$ & 89 & 8.7 & 80 & 30.4 & 37.19 & 3084 & 1.01 & 62.4 \\
\hline $\begin{array}{l}\text { UG } \\
\text { (ungraded) }\end{array}$ & 100 & 9.6 & 88 & 35.7 & 48.21 & 4108 & 1.40 & 72.7 \\
\hline SE \pm & 2.3 & 0.3 & 2.3 & 1.1 & 0.6 & - & - & 2.0 \\
\hline C Dat 5\% & 7.0 & 1.0 & 7.0 & 3.3 & 2.0 & - & - & 6.1 \\
\hline
\end{tabular}

Table 2 : Effect of different seed sizes and storage periods on quality of Lobia seeds during storage.

\begin{tabular}{|c|c|c|c|c|c|c|c|}
\hline \multicolumn{2}{|c|}{$\begin{array}{l}\text { Seed grades } \\
\text { and storage } \\
\text { months }\end{array}$} & $\begin{array}{c}\text { Germination } \\
(\%)\end{array}$ & $\begin{array}{c}\text { Speed of } \\
\text { germination } \\
\text { (Length / Day) }\end{array}$ & $\begin{array}{l}\text { Seedling } \\
\text { length }\end{array}$ & $\begin{array}{l}\text { Seedling } \\
\text { dry wt. (g) }\end{array}$ & $\begin{array}{c}\text { Seedling } \\
\text { vigour index } \\
\text { (SVI) }\end{array}$ & $\begin{array}{c}\text { Field } \\
\text { emergence } \\
(\%) \\
\end{array}$ \\
\hline \multirow[t]{5}{*}{ G1 } & Initial & 95 & 41.3 & 54.91 & 1.59 & 4405 & 81.2 \\
\hline & Dec 2015 & 88 & 39.94 & 53.04 & 1.49 & 4016 & 80.8 \\
\hline & Feb 2016 & 85 & 38.4 & 50.76 & 1.38 & 2941 & 75.1 \\
\hline & \begin{tabular}{|l} 
April \\
2016 \\
\end{tabular} & 80 & 36.01 & 45.01 & 1.21 & 2712 & 68.1 \\
\hline & $\begin{array}{l}\text { June } \\
2016\end{array}$ & 76 & 33.54 & 40.14 & 1.01 & 2274 & 71.4 \\
\hline \multirow[t]{5}{*}{ G2 } & Initial & 94 & 41.1 & 52.94 & 1.53 & 4391 & 80.8 \\
\hline & Dec 2015 & 90 & 40.23 & 50.98 & 1.50 & 4182 & 80.1 \\
\hline & Feb 2016 & 89 & 39.16 & 48.16 & 1.41 & 3991 & 81.2 \\
\hline & $\begin{array}{l}\text { April } \\
2016\end{array}$ & 88 & 38.14 & 46.01 & 1.32 & 3599 & 80.4 \\
\hline & $\begin{array}{l}\text { June } \\
2016 \\
\end{array}$ & 86 & 38.01 & 42.02 & 1.11 & 3091 & 78.4 \\
\hline \multirow[t]{5}{*}{ G3 } & Initial & 80 & 30.40 & 42.09 & 1.21 & 3084 & 62.4 \\
\hline & Dec 2015 & 70 & 28.04 & 41.12 & 1.14 & 2314 & 56.0 \\
\hline & Feb 2016 & 64 & 26.98 & 38.41 & 0.98 & 2221 & 50.1 \\
\hline & \begin{tabular}{|l} 
April \\
2016 \\
\end{tabular} & 63 & 23.89 & 35.94 & 0.90 & 2101 & 49.1 \\
\hline & \begin{tabular}{|l} 
June \\
2016 \\
\end{tabular} & 50 & 20.14 & 30.98 & 0.81 & 2002 & 33.0 \\
\hline \multirow[t]{5}{*}{ UG } & Initial & 88 & 35.7 & 48.21 & 1.40 & 3008 & 72.7 \\
\hline & Dec 2015 & 80 & 32.01 & 46.71 & 1.30 & 2814 & 70.2 \\
\hline & Feb 2016 & 77 & 30.16 & 44.02 & 1.20 & 2704 & 67.4 \\
\hline & $\begin{array}{l}\text { April } \\
2016 \\
\end{array}$ & 70 & 28.91 & 40.16 & 1.10 & 2499 & 60.2 \\
\hline & $\begin{array}{l}\text { June } \\
2016 \\
\end{array}$ & 64 & 27.41 & 37.01 & 0.98 & 2292 & 53.1 \\
\hline
\end{tabular}


Table 3: Effect of different Seed sizes and storage periods on incidence percentage of fungi on Lobia seeds during storage.

\begin{tabular}{|l|l|c|c|c|c|c|}
\hline \multirow{2}{*}{$\begin{array}{l}\text { Seed grades and } \\
\text { storage months }\end{array}$} & \multicolumn{5}{|c|}{ Percent fungi encountered on seeds of Cowpea } \\
\cline { 2 - 7 } & Aspergillus sp. & Fusarium sp. & Curvualaria sp. & Rhizopus sp. & Penicilliumsp. \\
\hline G1 & Initial & 2.5 & 0.25 & 0.50 & 0.50 & - \\
\hline & Dec 2015 & 5.00 & 0.75 & 2.00 & 1.50 & 0.75 \\
\hline & Feb 2016 & 10.25 & 4.00 & 4.50 & 3.00 & 1.75 \\
\hline & April 2016 & 20.00 & 5.75 & 6.00 & 5.75 & 2.75 \\
\hline G2 & June2016 & 30.25 & 8.00 & 9.75 & 8.75 & 4.00 \\
\hline & Initial & 1.00 & - & 0.25 & 0.25 & - \\
\hline & Dec 2015 & 4.75 & 0.25 & 1.25 & 1.75 & 0.25 \\
\hline & Feb 2016 & 8.25 & 2.25 & 3.25 & 3.75 & 1.25 \\
\hline & April 2016 & 18.00 & 4.00 & 5.00 & 5.00 & 2.00 \\
\hline G3 & June 2016 & 25.75 & 7.75 & 9.00 & 8.25 & 3.50 \\
\hline & Initial & 5.00 & 0.50 & 0.75 & 0.75 & 0.25 \\
\hline & Dec 2015 & 10.75 & 2.00 & 3.00 & 2.50 & 2.25 \\
\hline & Feb 2016 & 15.00 & 4.75 & 8.25 & 4.75 & 4.00 \\
\hline & April 2016 & 25.00 & 8.00 & 13.00 & 8.00 & 6.00 \\
\hline & June 2016 & 40.25 & 12.75 & 18.00 & 12.75 & 8.75 \\
\hline UG & Initial & 3.25 & 0.25 & 0.50 & 0.50 & 0.25 \\
\hline & Dec 2015 & 7.75 & 2.00 & 1.50 & 2.00 & 1.50 \\
\hline & Feb 2016 & 12.00 & 4.50 & 4.25 & $7 . .00$ & 4.50 \\
\hline & April 2016 & 18.25 & 66.75 & 6.00 & 7.00 & 4.50 \\
\hline & June 2016 & 328.00 & 8.75 & 11.75 & 9.75 & 6.00 \\
\hline
\end{tabular}

\section{References:}

Abdul Baki, A. A. and J. D. Anderson. 1973. Vigour determination in Soybean seed by multiple criteria. Crop. Sci. 10:31.34.

ISTA 1976. International rules for seed testing. Seed Sci. and Technol. 4: 108.

Aguir, L.B. DE and J.T. Nakane. 1983. Seed size of Eucalyptus citriodora, Influence on germination and vigour. Seed Abstr. 12.2576.

ISTA. 1985. International rules for seed testing. Seed Sci. and Technol. 13.299-513.

Barriga, C. 1961. Effect of mechanical abuse of navy bean seed at various moisture levels.Agron. J. (63) : 250-251.

Christensen, C.M. 1973. Loss of viability in storage microflora. Seed Sci. nad Technol. 1:547-562.

Charjan, S.K.U. and J.L. Tarar. 1991. Influence of seed size on germination and seedling vigour in Sunflower Biojournal 3 (1) : 47-50.

Charjan, S.K.U. and J.L. Tarar. 1992. Effect of storage container on germinability and mycoflora of Soyabean seed. Indian J. Agric. Sci. 62(7) : 500-502.

Charjan, S.K.U and J.L. Tarar. 1993. Studies on seed quality parameters and mycflora associated with bold nadshrivelled seeds of greengram. Biojournal 5 (1 and 2 ): 71-72.

Charjan, S.K.U. and V.R. Gupta. 1996. Impact of storage condition on fungal flora and germinability of gram seeds. J. Soils and Crops 6 (2) : 136-138.

Charjan, S.K.U., S.R. Wankhede and K.G. Jayade. 2006. Influence of seed size on germination and seedling vigour in cowpea varieties. In: Economics of sustainability of Dryland Agriculture, Nagpur, 2006: 67-69.

Charjan S. V. Mohod, S.Rokde, R. Gadewar, A. Lambat and $\mathbf{P}$. Charde (2011) Effect of seed size and storage time on soyabean seed quality. In: proc. International conference in Agricultural Engineering, Chonburi, Thailand Page No. C-27 to C-37.
Dharmalingam, C. and R.N. Basu. 1990. Maintenance of viability and vigour in sunflower. Seed Res. 18(1) : 15-24. Dwivedi, S.N. and T.N. Shukla. 1990. Effect of methods of storage on germinability and mycoflora on gram. Seed res. 18 (1) : 82-85.

Gurbanov, Y.V. nad Z.G. Bertii. 1970. Initial growth intensity in winter wheat in relation to seed size Fld. Crop. Abstr.25: 1275.

Kalakannawar, R.M., s.d.Shashidhara and G.N. Kulkarni. 1989. Effect of grading on quality of wheat seeds. Seed Res. 17: 182-185.

Kausal, R. T., S.P. Changode and V.N. Patil. 1993. Standardization of sieve sizes for grading crop seeds. Seed Research Special Vol. (2) : 826-834.

Maguire, J.D. 1962. Seed of germination and in selection and evaluation of seedling emergence and vigour. Crop Sci. 2. : 176-177.

Panse, V.G. and P.V. Sukhatme. 1967. Statistical methods for agril. Workers, I.C.A.R. Pub., New Delhi.

Reddy, M.R. and J. Subbayya. 1980. Mycoflora associated with dicoloured shriveled seeds of blackgram. Seeds and Farm $6: 32-33$.

Shrivastava, R.N. and J.S. Gupta. 1980. Effect of storage on the mycoflora and viability of pansy and verbena seeds. Seeds and farms. 6 (4) : 25-28.

Tiwari, M.N. and P.G. Guta. 1981. Effect of genotypes, seed grade and environment on viability and vigour of sunflower seed in storage, Seed Research 9(2): 126-131.

Tiwari, V.N. and A.S. Gontia. 2001. Effect of seed size on seedling vigour, yield and its contributing character in paddy. Ad. Plant Sci. 14(1): 111-114.

Vyas, R.P., Raghavendra Kumar, V. Prakash and R.P. Katiyar. 1990. Germinability of Soyabean Seeds after harvest in subsequent storage. Seed Res. 18(1): 44-46. 